\title{
A Study on Training Needs Assessment of Kiwi Growers in Lower Subansiri District of Arunachal Pradesh, India
}

\author{
Hage Yadii", M. Deepa Devi, M. Kunjaraj Singh and N. Okendro Singh \\ Department of Extension Education, College of Agriculture, Central Agricultural University, \\ Imphal, Manipur (India) \\ *Corresponding author
}

\section{A B S T R A C T}

\begin{tabular}{|l|}
\hline K e y w o r d s \\
$\begin{array}{l}\text { Training needs, } \\
\text { Kiwi growers, } \\
\text { Arunachal Pradesh }\end{array}$ \\
\hline Article Info \\
\hline $\begin{array}{l}\text { Accepted: } \\
18 \text { November } 2020 \\
\text { Available Online: } \\
10 \text { December } 2020\end{array}$ \\
\hline
\end{tabular}

\begin{abstract}
The study was conducted in Lower Subansiri district of Arunachal Pradesh to assess the training need areas of the kiwi growers. Majority of the respondents had medium level of training needs. Plant protection measures, propagation and planting, and climate and soil were the major top three areas perceived as priority areas in regard to training need areas of the respondents, and the least training need area was in the area related to flowering and pollination. The variables age, training exposure, economic motivation, extension contact and mass media exposure were found to be negatively and significantly correlated whereas educational status, size of land holding and innovation proneness were found to be positively significant with the training needs. Regression analysis showed that, five variables, namely age, land holding, annual income, training exposure and innovation proneness contributed significantly to the extent of training needs of the respondents and can be termed as good predictors that can be effectively used as a tool for the assessment of training needs of kiwi growers in Arunachal Pradesh.
\end{abstract}

\section{Introduction}

Kiwi fruit (Actinidia deliciosa var. deliciosa) known as 'China's miracle fruit' is native to China and has gained enormous popularity in the past two decades in many countries of the world. In fact, no other fruit has attracted so much attention in such a short period in the history of commercial fruit production.

The kiwi fruit is a temperate fruit crop; its cultivation is limited to certain temperate regions. Arunachal Pradesh is the leading producer of kiwi fruit in India with an area of
3,379 ha and an annual production of 6,047 tons. As of the year 2015-16, according to the National Horticulture Board (NHB), Arunachal Pradesh contributed to more than 50 per cent of the total kiwi fruit produced in the country.

India produces approximately about 8,500 tons of kiwi fruit; just one fourth of its total demand. India imports 75 per cent of its domestic demand for fresh kiwi fruit. In 2016, it imported 24,481 tons of fresh kiwi fruit by spending US\$ 32 million. Although Arunachal Pradesh is the leading producer of 
kiwi fruit in India, there still exists a lacuna to compete with the imported kiwi fruits. The farmers can progress economically if relevant technical know-how is imparted to them in context of kiwi fruit cultivation.

Training is a process of acquisition of new skills, attitude and knowledge in the context of preparing for entry into a vocation or improving one's productivity in an organization or enterprise. Effective training requires a clear picture of how the trainees will need to use information after training in place of local practices what they have adopted before in their situation. In order to make any training meaningful and effective, it is imperative on the part of the training organizers to identify the training needs of the farmers basing on which a suitable training module can be developed so that the right training is given to the right people, in the right form, at the right time and at the right costs so that higher degree of productivity and profitability can be achieved. Training of farmers essentially contributes to human resource development in agriculture.

\section{Materials and Methods}

The study was conducted in Lower Subansiri district of Arunachal Pradesh. Ziro-I block was selected purposively out of the two blocks in the particular district. All the seven villages and a town of the particular block were considered for selection of the respondents. A total of 104 kiwi growers were selected through random sampling method where eighty percent of the total kiwi growers from each village were selected.

The data were collected with the help of pre tested structured interview schedule through personnel interview method. For the present study, a list of 11 major areas of training needs in relation to improved package of practices of kiwi cultivation was prepared after consultation with scientists and experts. The training need areas of the respondents in the main areas training in relation to kiwi cultivation as perceived by them were measured by using a three point continuum scale i.e. Most Important(MI), Important(I) and Least Important(LI) with a score of 3, 2 and 1 respectively.

The relative needs for training in the main areas as perceived by the respondents were studied by working out the weighted mean score (WMS) and rank-order of the WMS. The weighted mean score (WMS) of training needs in the area of kiwi cultivation is the ratio of the total training needs score obtained by ' $n$ ' respondents in that particular area, to the total maximum possible score of ' $n$ ' respondents, expressed in a grade scale of 3 , i.e., the highest score in the response categories. Data so obtained were tabulated, classifieds and analyzed by percentage, mean, standard deviation, simple correlation and regression analysis using SPSS software.

\section{Results and Discussion}

Training needs in relation to improved package of practices of kiwi cultivation

Table 1 shows that majority (61.54\%) of the kiwi growers had medium level of training needs in relation to improved kiwi farming practices followed by high level of training needs (20.19\%) and low (18.27\%) level of training needs.

Important training need areas identified with respect to improved kiwi cultivation practices

Table 2 revealed that training needs of the respondents based on weighted mean score was found most important in the field of weed control having mean score of 2.19 and ranked I, followed by processing and marketing 
having mean score of 2.18 and rank II. Training was found important in the area of plant protection measures (Disease control, Insect-pest control) with mean score of 2.08 and having rank III followed by propagation and planting with mean score of 2.06 and ranked IV. Climate and soil, nutrient management, land preparation and layout were ranked V, VI, and VII with mean score of 2.03, 1.99 and 1.98 respectively. The area of training and pruning having mean score of 1.82 was ranked VIII. The areas of harvesting/storage and irrigation management had the mean scores of 1.75 and 1.64, and were ranked IX and X respectively. The least important training need area was identified as flowering and pollination having mean score of 1.41 and was ranked at XI position with respect to other training need areas. Thus, it may be inferred that the highest rank in order of training need areas was found in respect of weed control and the lowest rank was found in the area of flowering and pollination.

Table.1 Distribution of kiwi growers in accordance to their overall training needs scores $(n=104)$

\begin{tabular}{|c|c|c|c|c|}
\hline Sl. No. & Level of training needs & Score range & Frequency & Percentage \\
\hline $\mathbf{1}$ & Low & Upto 65.06 & 19 & 18.27 \\
\hline $\mathbf{2}$ & Medium & 65.06 to 96.88 & 64 & 61.54 \\
\hline $\mathbf{3}$ & High & 96.88 and above & 21 & 20.19 \\
\hline & Total & & 104 & 100.00 \\
\hline$\mu=80.97$ & $\sigma=15.91$ & & & \\
\end{tabular}

Table.2 Training need areas of farmers with respect to improved kiwi cultivation practices

\begin{tabular}{|c|c|c|c|c|c|c|c|c|}
\hline \multirow[t]{2}{*}{11} & \multirow[t]{2}{*}{ Area of Training } & \multicolumn{3}{|c|}{ Level of training needs } & \multirow[t]{2}{*}{ WS } & \multirow{2}{*}{\multicolumn{2}{|c|}{$\begin{array}{c}\text { Rank Overall } \\
\text { WS }\end{array}$}} & \multirow{2}{*}{$\begin{array}{c}\text { Overall } \\
\text { Rank }\end{array}$} \\
\hline & & MI & I & LI & & & & \\
\hline A. & \multicolumn{8}{|l|}{ Climate and Soil } \\
\hline i. & $\begin{array}{l}\text { Knowledge of climate type } \\
\text { appropriate for the crop }\end{array}$ & $\begin{array}{c}15 \\
(14.42)\end{array}$ & $\begin{array}{c}26 \\
(25.00)\end{array}$ & $\begin{array}{c}63 \\
(60.5)\end{array}$ & 1.54 & IV & \multirow[t]{4}{*}{2.03} & \multirow[t]{4}{*}{$\mathrm{V}$} \\
\hline ii. & $\begin{array}{l}\text { Knowledge of soil and soil } \\
\text { type }\end{array}$ & $\begin{array}{c}30 \\
(28.85)\end{array}$ & $\begin{array}{c}47 \\
(45.19)\end{array}$ & $\begin{array}{c}27 \\
(25.96)\end{array}$ & 2.03 & III & & \\
\hline iii. & Soil treatment & $\begin{array}{c}37 \\
(35.58)\end{array}$ & $\begin{array}{c}57 \\
(54.81)\end{array}$ & $\begin{array}{c}10 \\
(9.62)\end{array}$ & 2.26 & II & & \\
\hline iv. & Soil management & $\begin{array}{c}42 \\
(40.38)\end{array}$ & $\begin{array}{c}51 \\
(49.04)\end{array}$ & $\begin{array}{c}11 \\
(10.58)\end{array}$ & 2.30 & I & & \\
\hline B. & \multicolumn{8}{|l|}{ Propagation and Planting } \\
\hline i. & $\begin{array}{l}\text { Knowledge of Planting } \\
\text { material }\end{array}$ & $\begin{array}{c}21 \\
(20.19)\end{array}$ & $\begin{array}{c}57 \\
(54.81)\end{array}$ & $\begin{array}{c}26 \\
(25.00)\end{array}$ & 1.95 & V & \multirow[t]{5}{*}{2.06} & \multirow[t]{5}{*}{ IV } \\
\hline ii. & Varieties & $\begin{array}{c}47 \\
(45.19)\end{array}$ & $\begin{array}{c}49 \\
(47.12)\end{array}$ & $\begin{array}{c}8 \\
(7.69)\end{array}$ & 2.36 & I & & \\
\hline iii. & Method of propagation & $\begin{array}{c}11 \\
(10.58)\end{array}$ & $\begin{array}{c}53 \\
(50.96)\end{array}$ & $\begin{array}{c}40 \\
(38.46)\end{array}$ & 1.72 & VI & & \\
\hline iv. & Time of planting & $\begin{array}{c}40 \\
(38.46)\end{array}$ & $\begin{array}{c}41 \\
(39.42)\end{array}$ & $\begin{array}{c}23 \\
(22.12)\end{array}$ & 2.16 & II & & \\
\hline $\mathbf{v}$. & $\begin{array}{l}\text { Spacing (row to row and } \\
\text { plant to plant) }\end{array}$ & $\begin{array}{c}36 \\
(34.62)\end{array}$ & $\begin{array}{c}42 \\
(40.38)\end{array}$ & $\begin{array}{c}26 \\
(25.00)\end{array}$ & 2.10 & III & & \\
\hline
\end{tabular}




\begin{tabular}{|c|c|c|c|c|c|c|c|c|}
\hline vi. & $\begin{array}{l}\text { Treatment of planting } \\
\text { material }\end{array}$ & $\begin{array}{c}30 \\
(28.85)\end{array}$ & $\begin{array}{c}47 \\
(45.91)\end{array}$ & $\begin{array}{c}27 \\
(25.96)\end{array}$ & 2.03 & IV & & \\
\hline C. & \multicolumn{8}{|c|}{ Land preparation and Layout } \\
\hline i. & Pit size & $\begin{array}{c}7 \\
(6.73)\end{array}$ & $\begin{array}{c}50 \\
(48.08)\end{array}$ & $\begin{array}{c}47 \\
(45.19)\end{array}$ & 1.62 & III & \multirow[t]{4}{*}{1.98} & \multirow[t]{4}{*}{ VII } \\
\hline ii. & Male to Female ratio $\left(\delta^{\lambda}:+\right.$ ) & $\begin{array}{c}55 \\
(52.88)\end{array}$ & $\begin{array}{c}32 \\
(30.77)\end{array}$ & $\begin{array}{c}17 \\
(16.35)\end{array}$ & 2.37 & II & & \\
\hline iii. & $\begin{array}{l}\text { Identification / knowledge } \\
\text { of male and } \\
\text { Female plants }\end{array}$ & $\begin{array}{c}54 \\
(51.92)\end{array}$ & $\begin{array}{c}42 \\
(40.38)\end{array}$ & $\begin{array}{c}8 \\
(7.69)\end{array}$ & 2.44 & I & & \\
\hline iv. & $\begin{array}{l}\text { Row orientation (in N-S } \\
\text { direction) }\end{array}$ & $\begin{array}{c}8 \\
(7.69)\end{array}$ & $\begin{array}{c}35 \\
(33.65)\end{array}$ & $\begin{array}{c}61 \\
(58.65)\end{array}$ & 1.49 & IV & & \\
\hline D. & \multicolumn{8}{|l|}{ Training and pruning } \\
\hline i. & $\begin{array}{ll}\text { Knowledge } & \text { on } \\
\text { training/trailing system }\end{array}$ & $\begin{array}{c}32 \\
(30.77)\end{array}$ & $\begin{array}{c}46 \\
(44.23)\end{array}$ & $\begin{array}{c}26 \\
(25.00)\end{array}$ & 2.06 & I & \multirow[t]{3}{*}{1.82} & \multirow[t]{3}{*}{ VIII } \\
\hline ii. & $\begin{array}{l}\text { Time of training and } \\
\text { pruning }\end{array}$ & $\begin{array}{c}13 \\
(12.50)\end{array}$ & $\begin{array}{c}28 \\
(26.92)\end{array}$ & $\begin{array}{c}63 \\
(60.58)\end{array}$ & 1.52 & III & & \\
\hline iii. & $\begin{array}{l}\text { No. Of training and } \\
\text { pruning }\end{array}$ & $\begin{array}{c}29 \\
(27.88)\end{array}$ & $\begin{array}{c}33 \\
(31.73)\end{array}$ & $\begin{array}{c}42 \\
(40.38)\end{array}$ & 1.88 & II & & \\
\hline E. & \multicolumn{8}{|l|}{ Nutrient management } \\
\hline i. & $\begin{array}{l}\text { Recommended dose of } \\
\text { FYM }\end{array}$ & $\begin{array}{c}18 \\
(17.31)\end{array}$ & $\begin{array}{c}54 \\
(51.92)\end{array}$ & $\begin{array}{c}32 \\
(30.77)\end{array}$ & 1.87 & IV & \multirow[t]{5}{*}{1.99} & \multirow[t]{5}{*}{ VI } \\
\hline ii. & $\begin{array}{l}\text { Time of application of } \\
\text { FYM }\end{array}$ & $\begin{array}{c}21 \\
(20.19)\end{array}$ & $\begin{array}{c}45 \\
(43.27)\end{array}$ & $\begin{array}{c}38 \\
(36.54)\end{array}$ & 1.84 & V & & \\
\hline iii. & $\begin{array}{l}\text { Knowledge of fertilizers } \\
\text { and chemicals }\end{array}$ & $\begin{array}{c}32 \\
(30.77)\end{array}$ & $\begin{array}{c}29 \\
(27.88)\end{array}$ & $\begin{array}{c}43 \\
(41.35)\end{array}$ & 1.89 & III & & \\
\hline iv. & $\begin{array}{l}\text { Knowledge of bio- } \\
\text { fertilizers }\end{array}$ & $\begin{array}{c}36 \\
(34.62)\end{array}$ & $\begin{array}{c}51 \\
(49.04)\end{array}$ & $\begin{array}{c}17 \\
(16.35)\end{array}$ & 2.18 & II & & \\
\hline v. & $\begin{array}{l}\text { Usage and dosage of bio- } \\
\text { fertilizers }\end{array}$ & $\begin{array}{c}38 \\
(36.54)\end{array}$ & $\begin{array}{c}49 \\
(47.12)\end{array}$ & $\begin{array}{c}17 \\
(16.35)\end{array}$ & 2.20 & I & & \\
\hline F. & \multicolumn{8}{|l|}{ Irrigation management } \\
\hline i. & $\begin{array}{l}\text { The appropriate irrigation } \\
\text { time interval to be followed }\end{array}$ & $\begin{array}{c}64 \\
(61.54)\end{array}$ & $\begin{array}{c}32 \\
(30.77)\end{array}$ & $\begin{array}{c}8 \\
(7.69)\end{array}$ & 1.46 & III & \multirow[t]{3}{*}{1.64} & \multirow[t]{3}{*}{$\mathrm{X}$} \\
\hline ii. & Method of irrigation system & $\begin{array}{c}66 \\
(63.46)\end{array}$ & $\begin{array}{c}19 \\
(18.27)\end{array}$ & $\begin{array}{c}19 \\
(18.27)\end{array}$ & 1.55 & II & & \\
\hline iii. & $\begin{array}{l}\text { Knowledge of critical } \\
\text { stages for irrigation }\end{array}$ & $\begin{array}{c}34 \\
(32.69)\end{array}$ & $\begin{array}{c}45 \\
(43.27)\end{array}$ & $\begin{array}{c}25 \\
(24.04)\end{array}$ & 1.91 & I & & \\
\hline G. & \multicolumn{8}{|l|}{ Weed control } \\
\hline i. & Identification of weeds & $\begin{array}{c}26 \\
(25.00)\end{array}$ & $\begin{array}{c}30 \\
(28.85)\end{array}$ & $\begin{array}{c}48 \\
(46.15)\end{array}$ & 1.79 & III & \multirow[t]{3}{*}{2.19} & \multirow[t]{3}{*}{ I } \\
\hline ii. & Control of weeds & $\begin{array}{c}70 \\
(67.31)\end{array}$ & $\begin{array}{c}28 \\
(26.92)\end{array}$ & $\begin{array}{c}6 \\
(5.77)\end{array}$ & 2.62 & I & & \\
\hline iii. & Knowledge of weedicides & $\begin{array}{c}38 \\
(36.54)\end{array}$ & $\begin{array}{c}44 \\
(42.31)\end{array}$ & $\begin{array}{c}22 \\
(21.15) \\
\end{array}$ & 2.15 & II & & \\
\hline H. & \multicolumn{8}{|l|}{ Plant protection measures } \\
\hline a. & \multicolumn{8}{|l|}{ Insect-pest control } \\
\hline i. & $\begin{array}{l}\text { Identification } \\
\text { insects/pests }\end{array}$ & $\begin{array}{c}29 \\
(27.88)\end{array}$ & $\begin{array}{c}39 \\
(37.50)\end{array}$ & $\begin{array}{c}36 \\
(34.62)\end{array}$ & 1.93 & III & 2.08 & III \\
\hline
\end{tabular}




\begin{tabular}{|c|c|c|c|c|c|c|c|c|}
\hline ii. & Control of insect/pests & $\begin{array}{c}32 \\
(30.77)\end{array}$ & $\begin{array}{c}60 \\
(57.69)\end{array}$ & $\begin{array}{c}12 \\
(11.54)\end{array}$ & 2.19 & I & & \\
\hline iii. & Knowledge of insecticides & $\begin{array}{c}28 \\
(26.92)\end{array}$ & $\begin{array}{c}50 \\
(48.08)\end{array}$ & $\begin{array}{c}26 \\
(25.00)\end{array}$ & 2.02 & II & & \\
\hline b. & \multicolumn{8}{|l|}{ Disease control } \\
\hline i. & $\begin{array}{l}\text { Identification of plant } \\
\text { diseases }\end{array}$ & $\begin{array}{c}26 \\
(25.00)\end{array}$ & $\begin{array}{c}45 \\
(43.27)\end{array}$ & $\begin{array}{c}33 \\
(31.73)\end{array}$ & 1.93 & III & & \\
\hline ii. & Control of plant diseases & $\begin{array}{c}39 \\
(37.50)\end{array}$ & $\begin{array}{c}48 \\
(46.15)\end{array}$ & $\begin{array}{c}17 \\
(16.35)\end{array}$ & 2.21 & I & & \\
\hline iii. & $\begin{array}{l}\text { Knowledge of chemicals } \\
\text { and fungicides }\end{array}$ & $\begin{array}{c}40 \\
(38.46)\end{array}$ & $\begin{array}{c}45 \\
(43.27)\end{array}$ & $\begin{array}{c}19 \\
(18.27)\end{array}$ & 2.20 & II & & \\
\hline I. & \multicolumn{8}{|l|}{ Flowering and pollination } \\
\hline i. & $\begin{array}{l}\text { Knowledge of flowering } \\
\text { and pollination }\end{array}$ & $\begin{array}{c}10 \\
(9.62)\end{array}$ & $\begin{array}{c}23 \\
(22.12)\end{array}$ & $\begin{array}{c}71 \\
(68.27)\end{array}$ & 1.41 & I & 1.41 & XI \\
\hline J. & \multicolumn{8}{|l|}{ Harvesting/Storage } \\
\hline i. & $\begin{array}{l}\text { Appropriate time of } \\
\text { harvesting }\end{array}$ & $\begin{array}{c}25 \\
(24.04)\end{array}$ & $\begin{array}{c}32 \\
(30.77)\end{array}$ & $\begin{array}{c}47 \\
(45.19)\end{array}$ & 1.79 & II & \multirow[t]{3}{*}{1.75} & \multirow[t]{3}{*}{ IX } \\
\hline ii. & Method of harvesting & $\begin{array}{c}4 \\
(3.85)\end{array}$ & $\begin{array}{c}33 \\
(31.73)\end{array}$ & $\begin{array}{c}67 \\
(64.42)\end{array}$ & 1.39 & III & & \\
\hline iii. & Method of storage & $\begin{array}{c}34 \\
(32.69)\end{array}$ & $\begin{array}{c}42 \\
(40.38)\end{array}$ & $\begin{array}{c}28 \\
(26.92)\end{array}$ & 2.06 & I & & \\
\hline K. & \multicolumn{8}{|l|}{ Processing and Marketing } \\
\hline i. & $\begin{array}{l}\text { Grading and } \\
\text { standardization }\end{array}$ & $\begin{array}{c}34 \\
(32.69)\end{array}$ & $\begin{array}{c}44 \\
(42.31)\end{array}$ & $\begin{array}{c}26 \\
(25.00)\end{array}$ & 2.08 & III & \multirow[t]{3}{*}{2.18} & \multirow[t]{3}{*}{ II } \\
\hline ii. & Packaging & $\begin{array}{c}32 \\
(30.77)\end{array}$ & $\begin{array}{c}53 \\
(50.96)\end{array}$ & $\begin{array}{c}19 \\
(18.27)\end{array}$ & 2.13 & II & & \\
\hline iii. & $\begin{array}{l}\text { Marketing and market } \\
\text { information }\end{array}$ & $\begin{array}{c}56 \\
(53.85)\end{array}$ & $\begin{array}{c}27 \\
(25.96)\end{array}$ & $\begin{array}{c}21 \\
(20.19)\end{array}$ & 2.34 & I & & \\
\hline
\end{tabular}

Table.3 Correlation coefficient of socio-personal, psychological and communication attributes of the kiwi growers with their training needs

\begin{tabular}{|c|l|c|}
\hline Sl.No. & \multicolumn{1}{|c|}{ Variable } & Correlation coefficient ' $\mathbf{r}$ \\
\hline $\mathbf{1 .}$ & Age & $-0.557^{* *}$ \\
\hline $\mathbf{2 .}$ & Educational status & $0.303^{* *}$ \\
\hline $\mathbf{3 .}$ & Family type & $0.066(\mathrm{NS})$ \\
\hline $\mathbf{4 .}$ & Family size & $-0.119(\mathrm{NS})$ \\
\hline $\mathbf{5 .}$ & Size of land holding & $0.381^{* *}$ \\
\hline $\mathbf{6 .}$ & Annual income & $0.215^{*}$ \\
\hline $\mathbf{7 .}$ & Training exposure & $-0.613^{* *}$ \\
\hline $\mathbf{8 .}$ & Risk orientation & $0.003(\mathrm{NS})$ \\
\hline $\mathbf{9 .}$ & Innovation proneness & $0.194^{*}$ \\
\hline $\mathbf{1 0 .}$ & Economic motivation & $-0.335^{* *}$ \\
\hline $\mathbf{1 1}$ & Extension contact & $-0.241^{*}$ \\
\hline $\mathbf{1 2 .}$ & Mass media exposure & $-0.261^{* *}$ \\
\hline
\end{tabular}

**Correlation is significant at the 0.01 level (2-tailed).

*Correlation is significant at the 0.05 level (2-tailed).

NS- Non-significant 
Table.4 Regression coefficient for the training needs of kiwi growers

\begin{tabular}{|c|c|c|c|c|c|c|}
\hline Sl. No. & Independent Variables & B & S. E & $\begin{array}{l}\text { Regression co- } \\
\text { efficient (Beta) }\end{array}$ & t-value & Sig. \\
\hline & (Constant) & 3.152 & .561 & & 5.614 & .000 \\
\hline 1. & Age & -.018 & .023 & -.424 & $-5.520 * *$ & .000 \\
\hline 2. & Educational Status & -.032 & .024 & .023 & -1.384 & .170 \\
\hline 3. & Land Holding & .077 & .020 & .264 & $3.757 * *$ & .000 \\
\hline 4. & Annual Income & .000 & .000 & -.221 & $-2.935 * *$ & .004 \\
\hline 5. & Training Exposure & -.027 & .006 & -.478 & $-4.414 * *$ & .000 \\
\hline 6. & Innovation Proneness & .049 & .025 & .126 & $1.923 *$ & .057 \\
\hline 7. & Economic Motivation & -.015 & .011 & -.100 & -1.329 & .187 \\
\hline 8. & Extension Contact & .012 & .009 & .106 & 1.416 & .160 \\
\hline 9. & Mass Media Exposure & -.011 & .010 & -.096 & -1.152 & .252 \\
\hline
\end{tabular}

Dependent Variable: Training Needs

Note: ** Significant at 0.01 level of significance

*Significant at 0.05 level of significance

$\mathrm{R}=0.786 \quad \mathrm{R}^{2}=0.618 \quad$ F-value $=16.897^{* *}$

Relationship between the selected independent variables and the training needs of the respondents in relation to improved package of practices of kiwi cultivation

It is observed from table 3 that out of 12 variables age, training exposure, economic motivation, extension contact and mass media exposure were found to have significant and negative correlation with the training needs of the kiwi growers while educational status, size of land holding and innovation proneness had positive and significant relationship.

Table 4 reveals that out of the nine correlated independent variables fitted in regression analysis, five variables, namely age, land holding, annual income, training exposure and innovation proneness contributed significantly to the extent of training needs of the respondents.

Age, annual income, training exposure was found to be positively significant while land holding and innovation proneness was found to be negatively significant. Also, educational status, economic motivation, extension contact and mass media exposure were found to be non- significant.

Table further depicts that these significant variables contributed to the extent of 61.80 per cent of the variations in the training needs of the kiwi growers and also can be termed as good predictors that can be effectively used as a tool for the assessment of training needs of kiwi growers in Arunachal Pradesh.

In conclusion the findings has brought out specific training needs of the kiwi growers namely, weed control, processing and marketing, plant protection measures, propagation and planting. It can be resolved that there was a necessity to transmit scientific know-how to the farmers through appropriate and timely training in order to improve their information and awareness concerning improved kiwi production technology to intensify the production and productivity and ultimately raise their socioeconomic level through improved kiwi cultivation practices. 


\section{Acknowledgement}

The authors acknowledge the contributions of Hage Yadii, M. Deepa Devi, M. Kunjara Singh and N. Okendro Singh, College of Agriculture, Central Agricultural University, Imphal, Manipur (India) for their technical support and valuable contributions to the manuscript.

\section{References}

Anonymous. (2011). District Statistical Handbook of Lower Subansiri District.

Chawang, J.K. and Jha, K.K. (2010). Training Needs of Paddy Cultivators in Nagaland. Indian Research Journal of
Extension Education,10(1): 74-77.

Indianproductionofkiwi,nationalhorticultureb oard.http://apeda.in/agriexchange/Indi a\%20Production/India_Productions.as px?Cat $=$ fruit $\&$ hscode $=1048$ accessed on 28/4/19.

Mani, G., Kundra, A. and Haque, A. (2018). Kiwi Value Chain in Arunachal Pradesh: Issues and Prospects. Agricultural Economics Research Review, 31(1): 123-130.

Sajeev, M.V. and Singha, A.K. (2010). Capacity Building Through KVKs: Training Needs Analysis of farmers of Arunachal Pradesh. Indian Research Journal of Extension Education, 10(1): 83-90.

\section{How to cite this article:}

Hage Yadii, M. Deepa Devi, M. Kunjaraj Singh and Okendro Singh, N. 2020. A Study on Training Needs Assessment of Kiwi Growers in Lower Subansiri District of Arunachal Pradesh, India. Int.J.Curr.Microbiol.App.Sci. 9(12): 2640-2646. doi: https://doi.org/10.20546/ijcmas.2020.912.312 